\title{
Isolation and Biochemical Characterization of Canis Lupus Familiaris and Human Saliva against the Pathogenic Bacteria and Analysis of Antimicrobial Activity
}

\author{
Sahu Ajay Kumar ${ }^{\star}$, Acharya Prangya Paramita ${ }^{2}$, Swain Akash ${ }^{1}$, Pallath Karthika $\mathbf{S}^{3}$, Sinha \\ Rupali $^{4}$, Soni Abhisek ${ }^{1}$
}

${ }^{1}$ Dept. of Microbiology, Bangalore University, Bangalore, Karnataka, India

${ }^{2}$ Dept. of Biotechnology, Sambalpur University, Odisha, India

${ }^{3}$ Dept. of Bioscience, Mahatma Gandhi University, India

${ }^{4}$ Dept. of Botany, Purvanchal University, Uttar Pradesh, India

\begin{abstract}
A B S T R A C T
Saliva is mainly contain protein have an important role biological system of that oral cavity is closely associated with different type of disease, in our research work we took canis lupus familiaris saliva which because the composition of dog salivary proteome and with relationship with human are unclear. Salivary proteome have more than 2353 differentially expressed protein human and dog salivary. Protein related regeneration and healing process as fibroblast growth factor and epidermal growth factors regulated by dog salivary, animal saliva is also known as common source of allergen. The main of this study and research work was to identify the particular species and determine the prevalence of pathogenic bacteria in the saliva of canis lupus familiaris, the biochemical analysis is used to to identify the particular kind of bacteria was present in dog saliva and how its access to another bacteria through antimicrobial activity test was done. Canine saliva was tested for bacterial effect against pathogens relevant to the hygienic function of maternal grooming of the mammary. Bactericidal against coagulase positive staphylococcus and pseudomonas, e coli is the cause of highly fatal coliform enteritis of mammal. The oral proteomes of dog and human were appreciably different most probably cellular process, development process, multi cellular process, metabolic process, immune system process, biological adhesion is different according to the their biological appearance. These research work provide new information on canis lupus familiaris saliva composition and which type of bacteria is present it, and how will be beneficial for the study of dog saliva in diseased and health condition in future.
\end{abstract}

Keywords: Canis lupus familiaris saliva, Biochemical characterization, Antimicrobial Activity, Microscopic Analysis, pathogenic bacteria.

A R T I C L E I N F 0: Received 22 Jan 2019; $\quad$ Review Completed 25 March 2019; $\quad$ Accepted 20 April 2019; $\quad$ Available online 15 June 2019

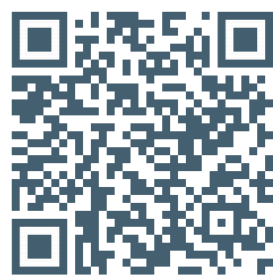

Cite this article as:

Sahu Ajay Kumar*, Acharya Prangya Paramita, Swain Akash, Pallath Karthika S., Sinha Rupali , Soni Abhisek Isolation and Biochemical characterization of Canis Lupus Familiaris and Human Saliva against the pathogenic bacteria and analysis of Antimicrobial Activity,, Asian Journal of Pharmaceutical Research and Development. 2019; 7(3): 54-58

\section{DOI: http://dx.doi.org/10.22270/ajprd.v7i3.474}

*Address for Correspondence:

Ajay Kumar Sahu Dept. of Microbiology, Bangalore University, Banswadi, Chilikere Ring Road, Bangalore, Karnataka, India

\section{INTRODUCTION}

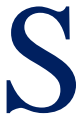
aliva is an important that maintain homeostasis in the oral cavity; mainly it contains variety of protein and peptide including enzyme and cytokines ${ }^{1-4}$. Saliva has main important function such as moistening foods and bolus formation, one of the best mechanisms of saliva the mucosal maintain the mineralization of teeth, dog and human saliva used in terms of medicine has been used in diagnostic test for oral disease, cancer and systemic lupus disease $^{7-9}$. Canis lupus familiaris saliva are the major reservoir for zoonotic infection, the main resident pathogenic bacteria and it relationship between oral bacteria and viruses can be transmitted to human mainly by infected saliva ${ }^{10,12,14}$. The dog salivary composition of proteome which may also associated by other groups of oral microorganism which influence the main cause of pathogenic bacteria cause the disease $\mathrm{e}^{10,12,15}$.

Dog saliva has more basic ph and higher buffering capacity than human saliva that has different electrolyte composition of in different kind of chemical such as calcium, potassium and sodium. The associated with human pathogenic bacteria and its relationship with that remain unclear, the alternation of human and dog saliva composition is vary by inflecting age, food consumption, environmental changes, and health condition may be 
increase the risk of dog associated with zoonotic infection $^{7,8,14}$.

Major protein and other chemical is identify by proteomic approach in dog and human salivary secretion were involved in the various groups of biological activity as well as involved in metabolism and the major bacteria characterize in human and dog saliva were related to cytoskeletal and also related to the inflammation $^{9,11,15}$. The major aim to isolate the particular bacteria which present in human and dog salivary and how its influence other kind of pathogenic and non pathogenic bacteria which is presently in environment and how it associated with them ${ }^{2,4,8}$. Basically the bacteria isolate from the saliva is determine and also identify their molecular basis characteristic by using of agarose gel electrophoresis, and the other biochemical characterization is identify the particular group of organism ${ }^{7,9,14}$.

\section{MATERIAL AND METHODS}

\section{Collection sample}

For dog saliva sample collection was done by one of veterinary doctor Dr. Alok Kumar Das, under the consideration the sample was taken from a Pet Dog. And human saliva was taken by our team member with suitable environment to main the sample contamination free.

\section{Saliva sample preparation for Gel electrophoresis}

Human and dog sample was take in different test tube and centrifuge for $15 \mathrm{~min}$ in $3000 \mathrm{Rpm}$ after the discarded supernant part and transfer the pallet part into a another centrifuge tube then added $2 \mathrm{ml}$ of acetone for precipitation of sample, then again centrifuge for $15 \mathrm{~min}$ in $5000 \mathrm{Rpm}$ then add mix the pellet with gel loading dye and processed for gel electrophoresis.

\section{Isolation of bacteria}

The bacteria was present in dog and human saliva was isolated by taken a agar media plate then added bacillus broth culture into the plate then few drops of saliva was added. Keep in incubator for 24 hours.

One more media plate was taking and we did the experiment by rubbing the hand in hair then put the hand in media plate because the microbes present in hair were transferred to the hand then after touching the hand in media plates the microbes was settle down on the plates. Then we added the saliva of dog and human saliva which was taken as sample, and then the plates were kept in incubators for the growth without any disturbance.

\section{Biochemical characterization}

\section{Biochemical characterization of isolates}

\section{Indole test}

Peptone broth was prepared and sterilized at $121^{\circ} \mathrm{c}$ for 15 min and inoculated with test organism, incubated the medium at $37^{\circ} \mathrm{c}$ for 24 hours. Added $1 \mathrm{ml}$ of kovac reagent to tubes including control

\section{Methyl Red test}

Prepared MR-VP broth in two flasks, inoculate the broth with the test organism and incubated for 24 hours at $37^{\circ} \mathrm{c}$, after 24 hours of incubation transferred $5 \mathrm{ml}$ of broth into two test tubes. To the each broth culture added 5 drops MR indicator the tubes and shake them.

\section{Voges proskauer test}

Prepared MR-VP broth in two flask, inoculates the broth with the test organism and incubated for 24 hours, prepared barritt reagent of A and B , After 24 hours all agar slant were examined for the presence of growth and coloration of the medium.

\section{Citrate utilization test}

Prepared citrate agar slant and inoculated each of the test organism into appropriately labeled tubes by means of a loop, the slant was left uninoculated that serve as control, incubated for 24 hours at $37^{\circ} \mathrm{c}$.

\section{Catalase test}

Transferred small quantity of culture from the plates on glass slide, added 1 drop of $3 \% \mathrm{H}_{2} \mathrm{O}_{2}$ observe bubbles.

\section{Oxidase test}

Taken oxidase disc in clean microscopic slide, pasted the culture on the oxidase disc and observed for color changes.

\section{Nitrate test}

Prepared nitrate broth and inoculated each of the test organisms into its appropriately labeled tubes means of a loop. The last slant was left uninoculated that serve as control, incubated all culture for 24 hours at $37^{\circ} \mathrm{c}$, after 24 hours add one dropper full of sulfanilic acid and one dropper full of $\alpha$ naphthylamine to each broth.

\section{Starch test}

Prepared starch agar and inoculated each of the test organism into its appropriately labeled tubes by means of a loop, the last plates was left un inoculated that serve as control, incubated all culture for 24 hours at $37^{\circ}$ c. after 24 hours all agar slants were examined for the presence of growth and zone formation on the medium.

\section{Gelatin test}

Prepared gelatin slant and inoculated each of the test organism into its appropriately labeled tubes by means of a loop. The slant was left un inoculated that serve as control, incubated all culture at the bacterium optimal growth temperature for up to 1 week and checked every day for gelatin liquefaction. Gelatin normally liquefies at $28^{\circ} \mathrm{c}$ and above, so to confirm that liquefaction was due to gelatinase activity.

\section{Identification of salivary bacteria}

Take a clean slide make a smear and heat fix it, flooded the fixed smear with crystal violet lets dry for 2 min, pour off the strain and gently wash tape water, flooded with grams iodine and allow it for 2 min then gently wash off with tape water shake off the excess water from the surface, decolorize with $95 \%$ ethanol for 3 seconds until the blue dye no longer flows from smear then finally add strains saffranin then observe under microscope.

\section{Antimicrobial activity by Agar-well diffusion method:}

The assay was conducted by agar well diffusion method. About $15 \mathrm{ml}$ of Nutrient agar medium was poured in the sterilized petri dishes and allowed to solidify. $50 \mu \mathrm{l} 24 \mathrm{hrs}$ active bacterial strains were taken and test strain was 
spread over the medium using a sterilized glass spreader. Using flamed sterile borer, wells of $4 \mathrm{~mm}$ diameter were punctured in the culture medium and required concentrations $(100 \mu \mathrm{l})$ of sample solution were added to the wells. The plates thus prepared were left for diffusion of extracts into media for $24-48$ hours incubated at $37 \mathrm{oC}$. After incubation for $48 \mathrm{~h}$, the plates were observed for zones of inhibition. The diameter of zone of inhibition

\section{RESULTS AND DISCUSSION}

was measured and expressed in millimeters. Plant aqueous extract was used as negative control.

\section{Agarose gel electrophoresis}

Agarose gel electrophoresis is methods used to separate a mixed population of macromolecules such DNA and protein in matrix of agarose, it is very easy methods to separate DNA of sizes range most often in laboratories.

Table: 1 Biochemical Characterization

\begin{tabular}{|l|l|l|l|l|l|l|l|l|l|}
\hline S. No & Indole & Methyl red & Vp test & $\begin{array}{l}\text { Citrate } \\
\text { utilization }\end{array}$ & $\begin{array}{l}\text { Catalase } \\
\text { test }\end{array}$ & $\begin{array}{l}\text { Oxidase } \\
\text { test }\end{array}$ & Nitrate test & Starch test & $\begin{array}{l}\text { Gelatine } \\
\text { test }\end{array}$ \\
\hline $\begin{array}{l}\text { Human } \\
\text { saliva }\end{array}$ & + & + & -- & + & -- & -- & + & + & -- \\
\hline Dog saliva & -- & -- & + & + & + & -- & -- & + \\
\hline
\end{tabular}

Table: 2 Gram Staining Test

\begin{tabular}{|l|c|c|}
\hline SI number & Human saliva & Dog saliva \\
\hline Gram positive & + & \\
\hline Gram negative & & -- \\
\hline
\end{tabular}

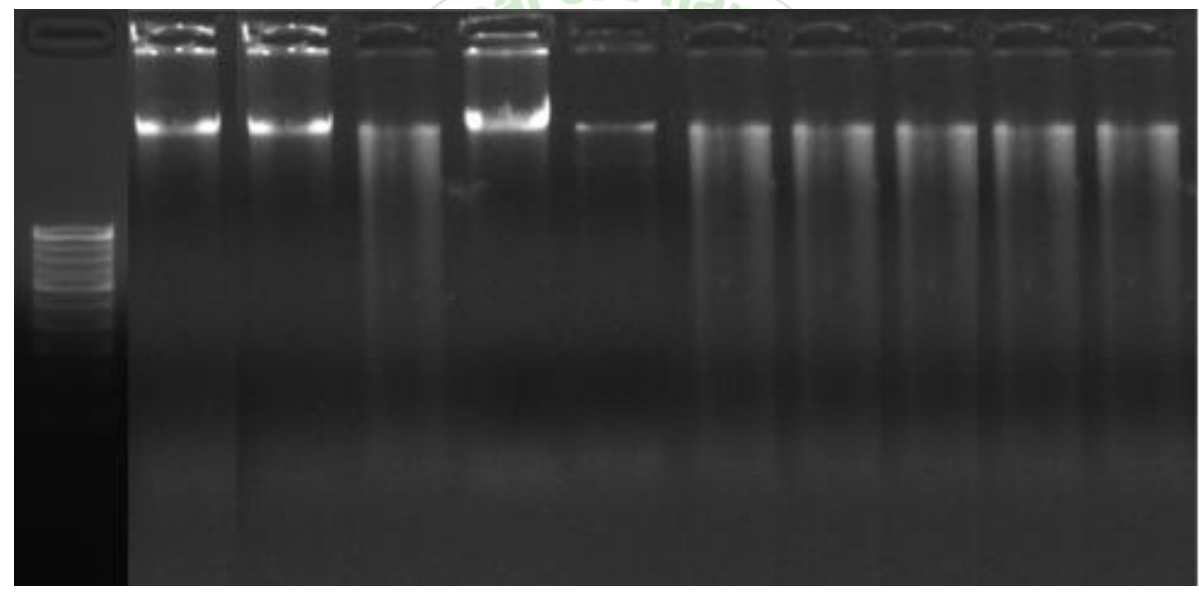

Figure 1: Agarose gel electrophoresis of human saliva

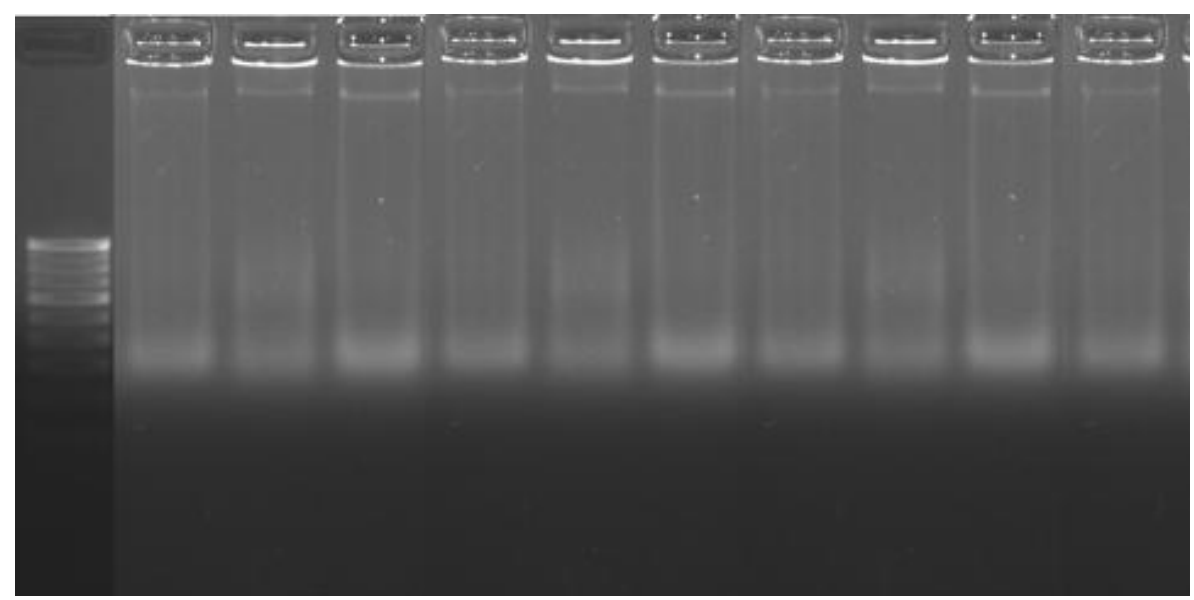

Figure 2: Agarose Gel Electrophoresis Dog Saliva 


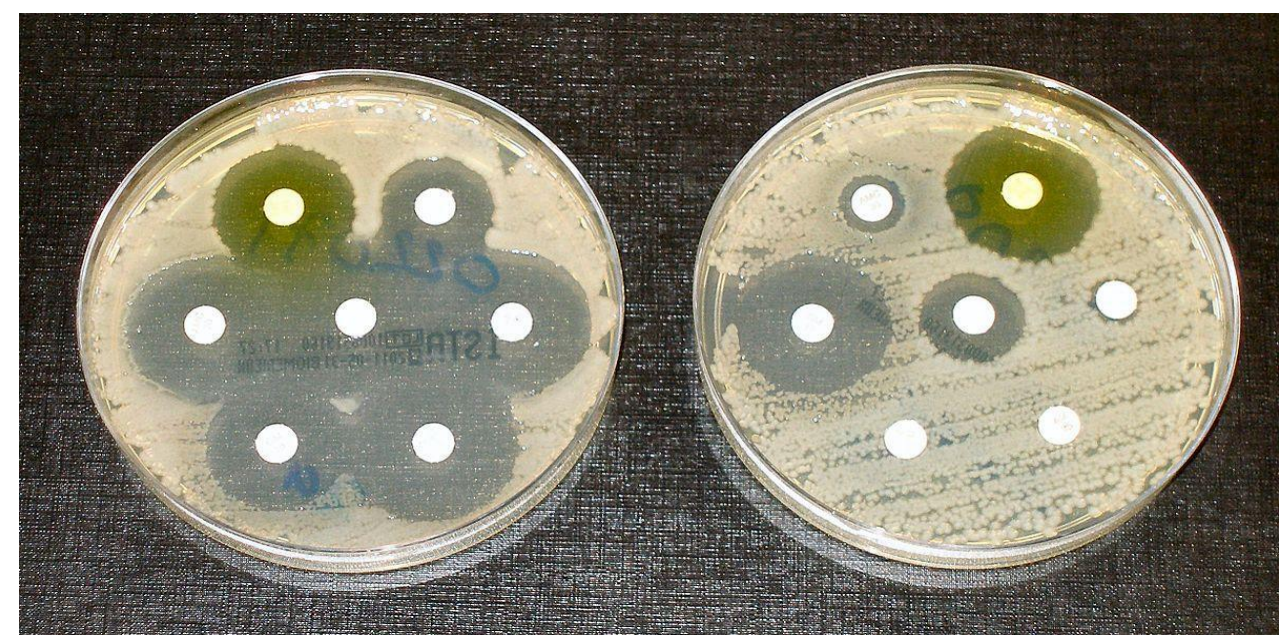

Figure 3: Antimicrobial susceptibility test of human saliva

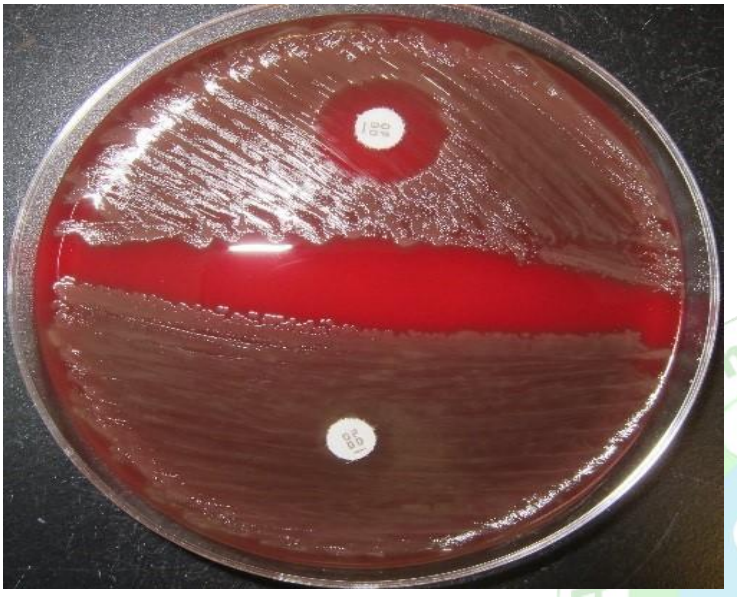

Figure 4: Antimicrobial susceptibility test of dog saliva

\section{CONCLUSION}

In dog saliva, helicobacter spp were found. DNA was detected in section of gastric mucosa often than in saliva sample, helicobacter heilmannii was the most frequently detected species in saliva sample of canis lupus femiliaris, it was found $29 \%$ of gastric sample and other species in saliva sample occurred much less frequently. The main conclusion of the research articles the comparison of the both dog and human saliva after growth of colony and the based on biochemical characterization was also identify the particular microorganism was subjected to that kind of microorganism. In the molecular basis of Saliva identification of DNA also varied by the band formation in the human saliva sample is more than the dog saliva sample, the particular specific band also concluded that dog and human saliva sample was specific differential by

\section{REFERENCE}

1. Bakri MM, evaluation of non invasive diagnostic test for helicobacter infection in symptomatic patient and health, Pakistan journal of physiology. 2015; 8:10-12.

2. Cellini L, Grande R, Artese L, Marzio L. detection of helicobacter in saliva and esophagus, new microbiology. 2010; 33:351-357.

3. Diker KS, Akan M, Celik S, Kabakci N. the prevalence, colonization sites and pathological effect of helicobacter in dog saliva, turkey journal vet animal science. 2002; 26:345-351.

4. Farrugia A, Keyser C, Ludes B. efficiency evaluation of DNA extraction and purification protocol on archival formalin fixed and paraffin embedded tissues, forensic science international journal. $2010 ; 194(4) ; 24-25$.

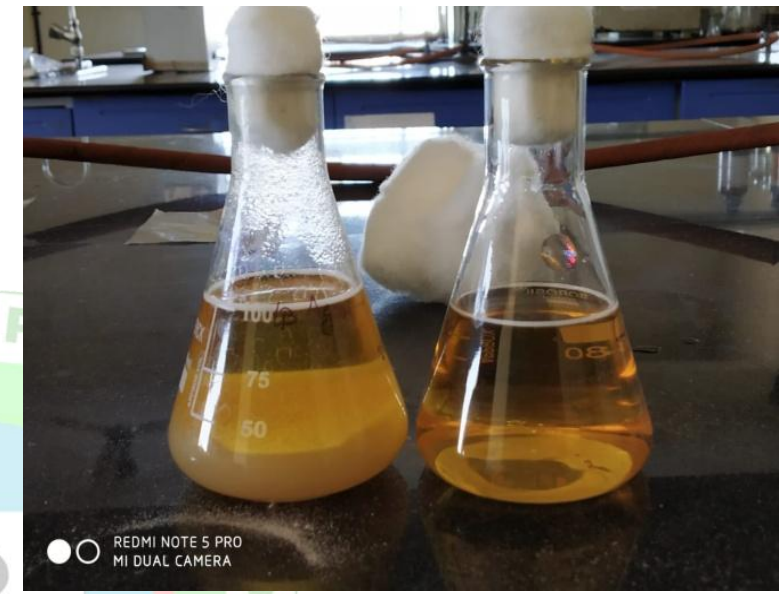

Figure 5: Bacteria growth in Lb broth media

their molecular basis. In antimicrobial susceptibility test also concluded that the zone of inhibition also can shown the particular groups of microorganism also be formed by indicated by their zones of inhibition, human saliva zones was less than dog saliva because of the present of bacteria in dog saliva helicobacter is form more amount of zones than human saliva.

\section{ACKNOWLEDGEMENT}

We gratefully acknowledge to Guide Dr. Rupali Sinha and karthika pallath for providing support in this research work and also thankful to my co- authors Prangya p. Acharya and Abhisek Soni to support me finical support as well doing all experiment.

\section{INTEREST OF CONFLICT - NIL}

5. Hongs S, Chung Y, Kang KG, Kim O, comparison of three diagnostic assays for identification of helicobacter spp, in laboratory dogs, lab animal research. 2015; 31(2):86-92.

6. Niger R, Burnens A, Goke B, Schmassmann A, diagnosis and identification of helicobacter species by PCR in dog saliva sample, microbiology ecology health disease. 1999; 11: 234-240.

7. Sjodin S, Fredriksson M identification of helicobacter DNA in feline pancreas, liver, stomach and formalin fixed paraffin embedded tissues sample, research vet science. 1991; 28-30.

8. Van den Bulck K, Baele M, Debongine JC, Burette A, Stolte M. identification of non helicobacter organism in saliva sample of human, dogs and cats, 2005, Journal of clinical microbiology. 2005; 43: $2256-2260$. 
9. Chiappin S, Antoneli G, Gatti R, Elio F. saliva specimen a new laboratory tools for diagnostic and basis investigation, clinical chim acta. 2007; 383:30-40.

10. Guarente L, Sirtuins, Aging and medicine, new engl journal medical. 2011; 364: 2235-2244.

11. Fitzpatrick J, Lendra RB, Jones CL, methods and device for detection of apo A, apo B and ratio there of saliva, 18 January. 2017; 234-456.

12. Dale BA, Fredericks LP, Antimicrobial in oral environment: expression and function in health and disease, current issues molecular biology. 2005; 117-119.
13. Akpomie OO, Ukoha P, Umukoro G, Saliva of different dog as antimicrobial agents against microorganism isolated from wounds infection, animal science journal. 2011; 2:18-22.

14. Lensen $\mathrm{cm}$, Moons CP, saliva sampling in dogs; How to select the most appropriate procedure for case study. Journal veterinary science. 2015; 10:504-512

15. Takagi K, Ishikura Y, Hiramatsu M, Nakamura K, Degawa M, Development of saliva collection device for use in the fields, clinical chim acta. 2013; 425:81-98. 